\title{
The Problems and Improvements in the China Rural "Assets Checkup" Work

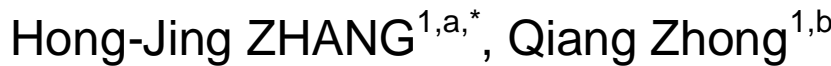

${ }^{1}$ School of Economics and Management, Northeast Dianli University, Jilin 132012, Jilin Province, China

azhanghongjing001@sina.com, b877046713@qq.com

${ }^{*}$ Corresponding author

Keywords: Assets checkup, Rural area, External auditors, the Readability checkup reports

\begin{abstract}
This article obtained from the rural area assets checkup, and analyzed the problems existing in the countryside assets checkup work,then gave some suggesstions for the rural assets checkup work, such as sorting out clear special subject, introducting of external auditors, writing the readable inventory report. If we can make the work perfect, then we can make the rural inventory datas as the supplement datas for the china third national economic census.
\end{abstract}

\section{Introduction}

Rural "collective assets" are the important materiales in the rural economic development. The rural " collective assets" management is also facing many new situations and problems. While the china goverment co-ordinats the development and integration of urbanization, industrialization and rural process, The perfect solutions of these problems or not are a matter of success or failure in the new socialist countryside construction, and it's also related to social stability and national security. The third national economic census datas do not include the first industry, but there is little no doubt that "SAN nong" basic datas are the important references in the country's macroeconomic policy formulation. This article obtains from the rural areas assets checkup work, and puts forward some suggestions to make the checkup work perfect, and makes the inventory data as supplementary data of the third national economic census data,so it can make the government macro economic decision more perfect.

The farmers have paid the attention to the mass to the "collective assets", in recent years, the rural financial work has obtained certain achievements and improvements. But in some areas, group financial management confusion, and some other problems still unresolved,This also causes some tensions between officials and the masses, so in order to strengthen " asset inventories" are the important contents of the rural financial management, in order to strengthen the management of assets must first strengthen the inventory of the "joint venture" work.

\section{The Scope of Rural Assets}

The rural collective assets are the rural collective economic organization resources, they are formed by long-term labor accumulation when people share common wealth,and they are belonging to the rural collective economic organization members, they also have the collective natures., owned by the collective economic organization members all together, protected by state law, no unit or individual can seize,transfer or divert it, these reflect that they are the special properties.

Rural collective funds refer to the rural collective cash or bank deposits owned by all collective members. The village collective assets refer to the form of past transactions or events, measured by money value, and they are owned or controlled by the rural collectives, and they are expected to 
bring economic benefits to the rural collective members. The rural collective resources refer to the rural collective materials and financial resources, the floorboard of the various material, such as human factors, and they are divided into two categories: natural resources and social resources. Natural resources including water, land, forest, grassland, animal, mineral, etc, social resources including human resources, information resources and cultural tourism resources, and through labor to create a variety of material wealth, such as technology, humanities landscape, etc.

\section{The Problems Existing in the Rural Areas Assets Checkup Work}

\section{The Ambiguity of the Principal Parts Inventory}

For now, there are some problems on the rural collective assets checkup work,such as, the villagers informed degree is not high, the ownership responsibility consciousness is not strong enough. In some areas, village cadres do all financial matters of the village without the participating of the collective members, the assets operating work are completely under the control of some village cadres, in the long term, not only do not have scientific and standardized accounting financial work, but also the village cadres can not get effective supervision,and corruption at the grass-roots level can appear, and the masses of tension situation can not moderate in the long run., rural grassroots autonomy with the democratic elections, democratic decision-making, democratic management and democratic supervision in some areas turn into a paper empty talk..

\section{Checkup Methods are Not Scientific}

The rural assets checkup work involved a large range and special objects. The rural collective resources of human are the important contents in the rural assets. These resourses don't have the general assets characteristics.so, they are not necessarily reasonable in measureing them by money value,. This do not consider its specia attributes, The rural collective land is also very important in the rural assets items. Rural grassroots land has the following characteristics, First, the special owned by the rural collective property rights nature, Second, if we use the traditional assets evaluation methods on the valuation, it is not reasonable.

\section{Insufficient Checkup Work Regulations}

The current checkup work are mainly composed of village self checking, county and the relevant administrative departments at or above the county level are responsible for the management of the rural collective assets, resources evaluation, and supervision. On the one hand, because of the rural masses on the supervision of the village was not enough, the participation and ownership responsibility consciousness is not strong enough to the checkup work, the assets checkup work is the monologue of some local village cadres. on the other hand, the management of operation is closely related to the village cadres, if the work is doing by the village cadres, the problems will not be found.

\section{The Conclusion is Not Standard}

The current assets checkup report is still using the standard of the enterprise assets liquidation.Not only do it not take the special attributes into account, but also do it not consider the basic needs of of the actual situation of rural grassroots and the subject of a special reading. The rural collective members have the ownership of collective property,they enjoy the rights to know the actual existence and operating conditions of the collective assets, in actual, The current checkup reports do not with that in mind,and the report also is not specific.such as, the description of the monetary measurement assets are not clear,the report is only dominated by money value, the 
resources which can't measured by monetary shall not be disclosed or rarely disclosed. The direct consequence is that the checkup results are not clear.

\section{Relevant Improvement Measures of the Problem}

\section{Determine the Checkup Body Under the Supervision of the Villagers Committee}

Rural grass-roots mass self-government system is a basic political system of china,it have democratic elections, democratic decision-making, democratic management and democratic supervision.,so, the checkup work should be making the incorporated villages as the unit, the assets checkup work should be under the supervision of the villagers committee, in the work, we should consider the assets particularity attributes that the rural collective assets belongs to the rural collective members of all together.it must rely on the masses of peasants, and protect their right to know, to participate, to supervise, and we should arouse the enthusiasm of them, and stimulate their sense of ownership. At the same time,the work must combinate with the practical situation of villages, the most important is to ensure the stability of the rural area.

We must stick to the unchanged principle that the rural collectivemembers have the rights of using, supervision, disposition.and we must safeguard the legitimate rights and interests of the rural collective members.

\section{On the Basis of Fully Considering the Particularity of Assets to Determine the Relevant Assets Value}

The fixed assets,organizations at the grass-roots level mainly includ house building, water conservancy facilities and some office appliance, etc. Because of the history and the cause of the accounting system is not sound,some assets have not booked in time. Such as the old buildings, we are unable to get the historical cost when they are obtained. also we have no depreciation of it. Also, some assets' original documents are lost, we are unable to trace the initial costs of these assets, for these kind of assets, we can hire professionals using appropriate approaches to valuate it, suggest using the replacement cost method or the liquidation price method.

The rural collective resources owned by the village collective economic organization members together, these assets are generally not having reasonable market price for reference, and also the future economic benefits cannot be determined exactly and reliably. In view of the particularity of the assets, if we evaluate them with money value, it is not necessarily reasonable and poor maneuverability. For these types of assets, we can create detailed parameter, and detail list of these assets with shape, location, area, the ownership, development status, etc. For the transfer of collective resources, pay more attention to whether there are illegal behavior when transfer,or sell the collective assets.

\section{The Introduction of External audit Institutions to Participate}

Although the checkup work should be under the villager autonomy of villagers' committee, but because of their own professional limitations and independence,we need to consider the participation of intermediary service agencies in terms of checkup assets and assessment.

Assets checkup work is one of the audit work, if the task is performed by the villagers committee, we could not find the existing problems. This is obviously not conforming to the independence required by audit work, at the same time, it does not have a professional competence required by the assets checkup work. The intermediary service institutions have the professional practice through education, training. They can ensure them to provide professional standards work.

For the charging problem,we must consider the economic capacity of incorporated villages.if 
charge too high, some incorporated villages do not necessarily able to endure, the high fees are not the case that we don't engage the intermediary service agencies, we need to solve the problem that who pay for the audit fees.

\section{To Write the Readable Checkup Report}

After the checkup work, the special audit report shall be issued, the special audit report according is the report that the certified public accountants express an opinion on the financial statements of the commpany,then write an document in terms of the Chinese Certified Public Accountants Auditing Standards. But considering the particularity of the rural assets, the checkup special report is different from general to specific audit report, the particularity is that it considers the special reading body of the report----the collective member of the rural areas, the specific reason is that the collective members of the rural areas are the actual the principal, agencies should report the assets' actual conditions to them, the agencies should be fully aware of this in the process of writing the audit report. When writing the report they should make the audit language more readable under the guidance of auditing standards. Also they should write a more professional special audit report for the examination of the certified public accountant.

For the assets which can be valued by the money value availably, we should fully disclosure the assumptions and constraints and other evaluate relevant informations necessarily in the assessment reports. For the assets which can't be valued by the money value availably, we should make a fully disclosure in the special report, stating the technical means that are adopted in the process of checkup work process, and explaining the reasons for using them for processing method.

\section{Conclusion}

The rural assets checkup work has not been fully carried out in china, the work will be complicated and arduous in the future, at the same time, the third national economic census range does not include the first industry, so the work can also make a supplement data sources for the third national economic census, This paper discusses the problems of the rurale assets checkup work.,and make an analyse of the main problem existing in the assets checkup work, and put forward some relevant improvement measures . Hoping to do benefits to the assets checkup work.

\section{References}

[1] The Treasury finance cadre training textbook editors committee at the local level,M. The rural collective economic organizations'assets management.(2011)

[2] China association of certified public accountants,M.auditing.(2012) 